\title{
Analysis of intergranular corrosion in welded joints with ferritic stainless steel ISI 409 and AISI 439 for application in vehicular exhaustion systems
}

\author{
Rafael Alves de Amorim ${ }^{1}$; Susana Marraccini Giampietri Lebrão ${ }^{1}$; Marco A. Colosio² \\ José Agustín Castillo Lara ${ }^{3}$ \\ ${ }^{1}$ Centro Universitário do Instituto Mauá de Tecnologia; \\ ${ }^{2}$ General Motors Mercosul; \\ ${ }^{3}$ Fundação Santo André
}

\begin{abstract}
The goal of this work consist of evaluating the sensibility of intergranular corrosion in welded joints of AISI 409 e AISI 439 applied in vehicular exhaustion systems, considering the type of welding process as being manual and automatic. For acquiring the test results were performed in DL-EPR (Reactivation of Duplo Loop Dynamic Potential) with $0,5 \mathrm{M}$ of $\mathrm{H}_{2} \mathrm{SO}_{4}$ in $25^{\circ} \mathrm{C}$, and mass lost according to ASTM A763 (Procedure X) for corrosion intergranular and ASTM G 48 (Method A) for pit corrosion. The results showed that corrosion depends on alloy elements in those steels and the increase of temperature in base metal due to weld wire speed.
\end{abstract}

\section{BACKGROUND}

The stainless steels were developed by Harry Brearly ((1871-1948) in Sheffield (England). In 1912, by interest of arm suppliers, that requested to Harry a new metallic alloy which could improve the wear resistance in the inner gun pipe. However, during this development in a certain step of tests, as the chemical etching, Brearly noted that Nitric Acid had no corrosive effect on steel surface. Brearley, so realized that his study had found out a new alloy resistant under corrosion, different from of the initial objective, which focused on wear resistance improving. (COBB, 2010)

The stainless steels consist of steels with high content of chromium, nickel, molybdenum in their composition. Those alloy elements, in specific chromium, promote an excellent corrosion resistance in comparison to common mild carbons. However, chromium element presents in those steels, by an oxidation reaction with oxygen inside of material, forms a thin and surface stable layer, which cause an excellent surface protection against to environment, as corrosion and oxidation. This thin layer is known as passive layer and has the characteristic of a surface protection much appreciate for many severe environmental applications. For reaching effectivity of this case, the minimum content of chromium must be around to $11 \%$ in steel; then it is a those important parameters for controlling in manufacturing process. (FERREIRA, 2006). Besides that, the stainless steel is a material with $100 \%$ of recyclability and low cost of maintenance, therefore could be applied in several domestic items as furniture parts, cutlery, refrigerator, oven and others.

The stainless steels are classified normally in austenitic (grades 300), ferritic e martensitic (grades 400), crystalline structures, but only the austenitics are magnetics, show excellent ductility, corrosion resistance, and withstand a wide temperature range in work. However they are relatively expensive and present a low mechanical strength, high melting point and a crystalline structure of face-centred cubic constituted by $\mathrm{Fe}, \mathrm{Cr}$ and $\mathrm{Ni}$, and finally, they are rarely hardened by quenching heat treatment. (MEI, 1988). 
The ferritic stainless steels are magnetic and present a good ductility, corrosion resistance and relatively a lower cost, however, their good mechanical properties are reduced in high temperatures, as consequent that, they may not be applied in severe stress conditions and normally their corrosion resistance is lower than austenitics grades. The ferritic grades present body-centered cubic structures constituted of $\mathrm{Fe}$ and $\mathrm{Cr}$.

The intergranular corrosion is a type spot corrosion, which may cause, sometimes, abrupt and critical failures, although the remaincent structures continue working. The corrosion mechanism theory explained by scientific community approaches the reduction of chromium content, which causes the presence of precipitates rich in chromium at the grain boundaries and the probably restriction of chromium content in adjacent regions, as normally named of sensitization phenomenon. If the chromium reduction in around of $10.5 \%$, the passive chromium layer formed in steel surface is totally eliminated and the steel lost the good corrosion properties. (SERNAGIRALDO, 2006).

Modenesi (2001) argued that in general the ferritic stainless steels present a poor ability of receive welding application, particularly in comparison with the austenitics steels, due to their weld to be normally characterized as low ductility and toughness, moreover the high sensibility in intergranular corrosion occurrence is a bad problem too.

Cracks formed in solidification stage may also occur in melted zones. In general, the weld embrittlement is more severe in steel with high chromium contents and interstitial elements and the intergranular corrosion susceptibility is more critical for higher interstitials elements contents and lower chromium content (FERREIRA, 2006).

Ferritic stainless steels with about Cr 12 to 13\% (AISI 409) in general, may be welded focusing on the adequate properties. However, those with higher chromium contents (AISI 430, 442, 446, etc.) are more sensible in embrittlement phenomenon during the welding processes. This effect is more sensitive in steels with higher interstitials elements (MODENESI, 2001).

\section{EXPERIMENTAL}

The chemical composition of steels AISI 409, AISI 439 and the 430 Ti tubular weld wire, and the welding parameter used, are show in Tables 1 and 2.

Table 1: Chemical composition of ferritic stainless steels AISI 409 and AISI 439 and Ti tubular wire, $430 \mathrm{Ti}$ (A.T.430Ti).

\begin{tabular}{cccccccccc}
\hline \multicolumn{10}{c}{ Chemical composition (\%) } \\
\hline & C & Si & Mn & P & S & Cr & Ni & Ti & Mo \\
\hline AISI 409 & 0.0080 & 0.4800 & 0.2700 & 0.0260 & 0.0004 & 10.81 & 0.2800 & 0.2300 & 0.0250 \\
\hline AISI 439 & 0.0080 & 0.4700 & 0.2400 & 0.0300 & 0.0004 & 17.23 & 0.2700 & 0.1320 & 0.0280 \\
\hline A.T.430Ti & 0.0210 & 0.7400 & 0.7500 & 0.0210 & 0.0010 & 17.74 & 0.2500 & 0.3800 & 0.0300 \\
\hline
\end{tabular}


Table 2: Welding parameters of AISI 409 e AISI 439 steels.

Welding parameters of AISI 409 e AISI 439 steels

\begin{tabular}{cccccc}
\hline Welding & $\begin{array}{c}\text { Wire speed } \\
\left(\mathbf{m . m i n}^{-\mathbf{1}}\right)\end{array}$ & $\begin{array}{c}\text { Voltaic arc } \\
\text { size }\end{array}$ & $\begin{array}{c}\text { Gas fow rate } \\
(\mathbf{L} / \mathbf{m i n})\end{array}$ & $\emptyset$ wire $(\mathbf{m m})$ & Type of weld \\
\hline manual & 12 & -15 & $10 \mathrm{a} 15$ & $1.0 / 430 \mathrm{Ti}$ & Pulse \\
\hline automatic & 3.0 a 7.0 & -22 a -5.0 & 10 a 15 & $1.0 / 430 \mathrm{Ti}$ & Pulse \\
\hline
\end{tabular}

Figure 1. Vehicular exaustion system;

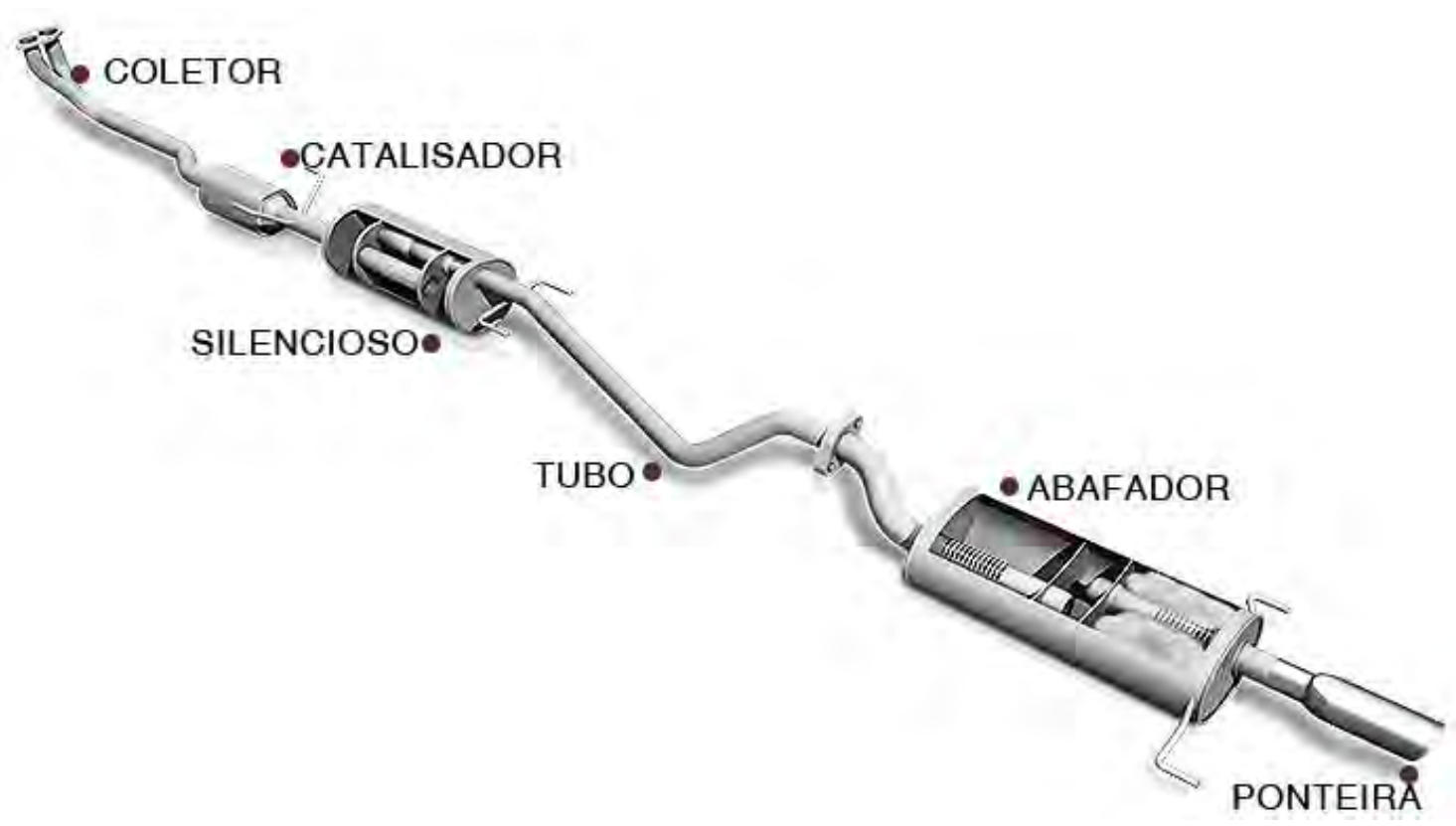

Ref.: http://www.blog.connectparts.com.br/escapamento-esportivo-como-funciona/

The samples were manufactured in the form of welded joints supplied by a local carmaker. First, the samples were mounted in Bakelite and prepared adequately to the DL-EPR test. It was necessary grind the samples with sandpaper number 600, performed a threaded hole in each sample and added a metal stem for electric contact between stem and the samples. After stem preparation, it was necessary to seal the threaded by Teflon tape, avoiding the presence of the test liquid, interfering in the results.

It was prepared a solution of $0,5 \mathrm{M}$ of $\mathrm{H}_{2} \mathrm{SO}_{4}$ in two recipients. One recipient received samples and Luggin capillary and the second was put a platina wire and a silver electrode. The samples stayed up to 5 minutes before being applied a stabilization current for corrosion potential. The potentiostat used was the AUTOLAB PGSTAT302N.

After performing the DL-EPR test, it was necessary to acquire new samples, because the previous one did not have a minimum area requested in test specification. The new samples were submitted in Practice X according to ASTM A763. Following the standard, the test was performed in boiling stage, however, when the samples were dipped in solution, those presented severe corrosion in 2 minutes. In this case, the practice was modified and the test performed in. 
At this case, the procedure was modified and the test performed with solution in room temperature. It was determined the surface area of each sample and after, they were weighed before diving in $\mathrm{Fe}_{2} \mathrm{SO}_{4}$ solution. After $24 \mathrm{~h}$, samples were removed from solution and weighed again, evaluating the final mass.

The samples were also submitted in method A according to ASTM G48. For this test, a solution $1000 \mathrm{~mL}$ of $\mathrm{FeCl}_{3}$ was prepared, for those new samples, it was determined initially the surface area and mass and subsequently, they were diving in solution during $72 \mathrm{~h}$, then those were removed from solution and weighted again, capturing the final mass.

For empirical calculations of mass lost or corrosion rate, a density of 7,8 g/cm3 was considered in, and a $\mathrm{K}$ constant of 87600 considering in $\mathrm{mm} /$ year rate (constant acquired in ASTM G1). According to standard G1, it was applied the following equation for corrosion rate evaluation:

$$
\text { Corrosion Rate }=\frac{(K * W)}{(A * T * D)}
$$

Being $\mathrm{K}$ a constant in accordance with to unit applied, $\mathrm{W}$ is mass lost in gram, $\mathrm{A}$ is he area in $\mathrm{cm}^{2}$, $\mathrm{T}$ the time in hours for exposition and $\mathrm{D}$ the density in $\mathrm{g} / \mathrm{cm}^{3}$.

\section{RESULTS AND DISCUSSION}

According to result obtained in double loop dynamic potential (DL-EPR), it was not possible to obtain a classic curve for stainless steels, conform observed in Figure 1. The test was performed following the same parameters of the article SERNA-GIRALDO et. all, 2007, and the results are showed in Figure 2. However, Serna-Giraldo (2007) performed test only in TAZ regions, at this work, the samples consisted of complete welded joints. Thought that, the difficult in obtaining a classic curve was due to a probably bi-metallic pair between stainless steel and the melted joint, avoiding reaching the desired results.

Figure 2. DL-EPR classic curve of a stainless steel (SERNA-GIRALDO, 2007)

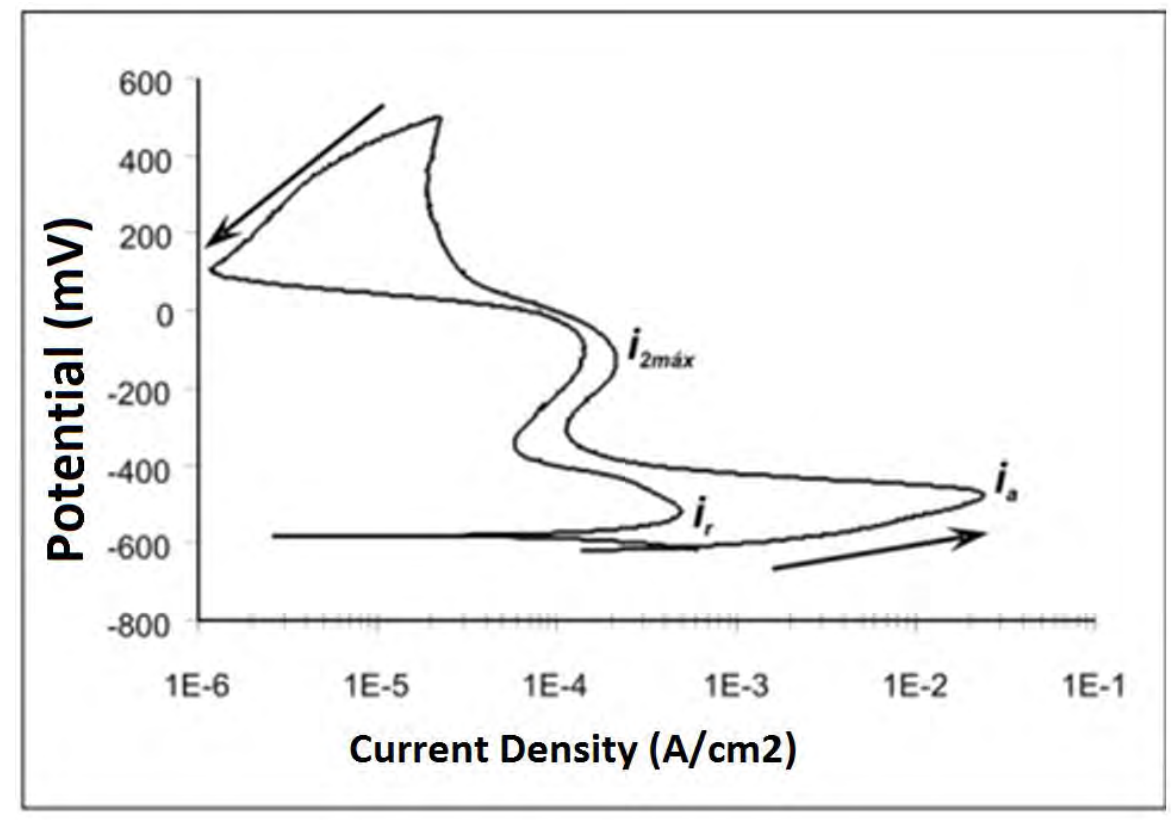


Figure 3. Curve obainned in DL-EPR test.

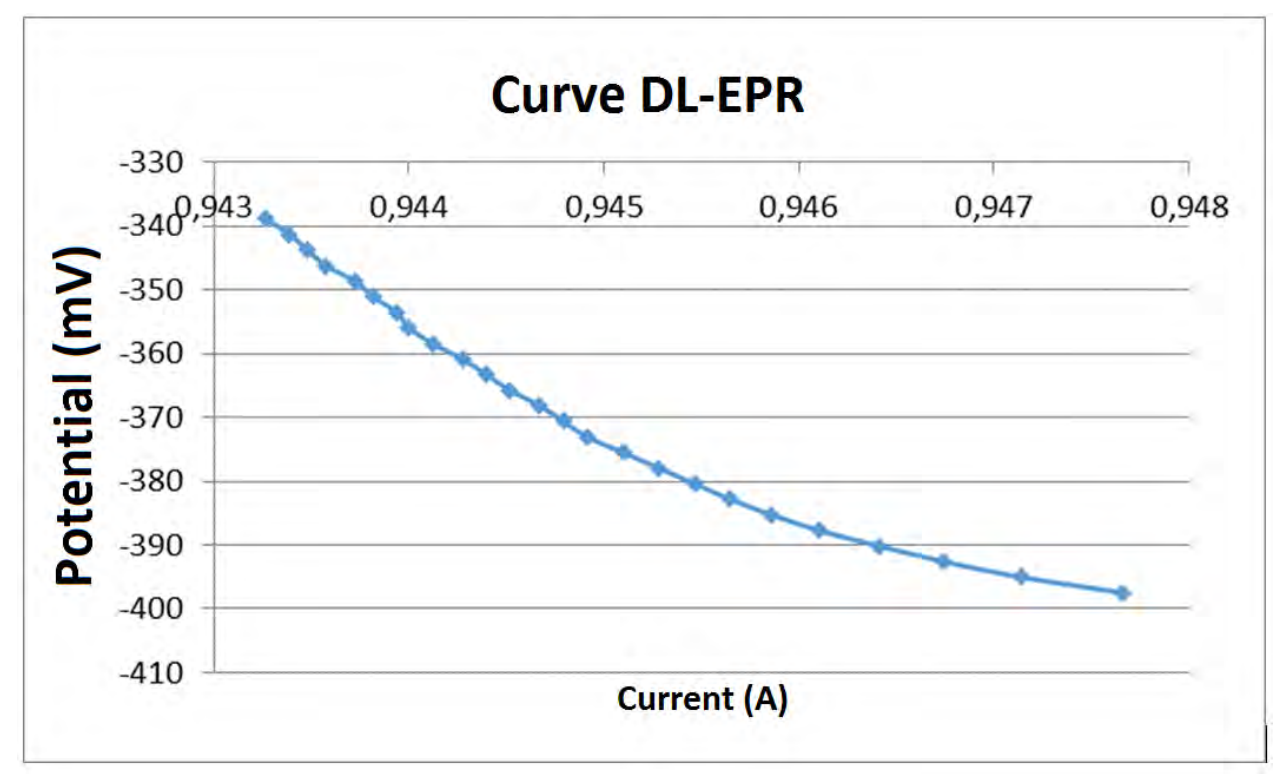

The Table 3 shows the intergranular corrosion rate for both stainless steels. The two steels were diving in of $\mathrm{Fe}_{2} \mathrm{SO}_{4}$ solution, but the 409 steel stayed 20h crowded in solution, and the 439 steel stayed $24 \mathrm{~h}$. This time variation was decided because a severe corrosion was noted in 409 steel.

Note that, the 409 steel presented a corrosion rate higher in comparison with 439 steel, this certainly happened due to higher quantities of alloy elements present in 439 steel. See the Table 1, the percentage of Chromium is higher in 439 steel, and as consequence, the chromium has a strength influence in ferrite phase stability.

In reference to weld processes in the steel 409 , it was performed manually and after, during the corrosion test noted a higher corrosion rate in this condition, different from expected, because the welding speeds involved in those processes are different, and certainly should be more critical in automatic process, which is slower than manual, and should affect more thermally the material in automatic process, occurring more chromium precipitate at grains boundaries.

Table 3: Solving the corrosion rate according to ASTM A763 Practice X.

\begin{tabular}{cccccc}
\hline \multicolumn{5}{c}{ Corrroion Rate (mm/year) } \\
\hline & $\begin{array}{l}\text { Area } \\
\left(\mathbf{c m}^{2}\right)\end{array}$ & $\begin{array}{l}\text { Initial mass } \\
(\mathbf{g})\end{array}$ & $\begin{array}{l}\text { Final mass } \\
\text { Final }(\mathbf{g})\end{array}$ & $\begin{array}{c}\text { Cost mass }(\mathbf{g}) \\
(\mathbf{m m} / \text { Ano })\end{array}$ \\
\hline $\begin{array}{c}\text { AISI 439 1,5 } \\
\text { Welder }\end{array}$ & 6,280 & 5,990 & 4,960 & 1,030 & 25,63 \\
\hline $\begin{array}{c}\text { AISI 439 1,5 } \\
\text { FIP }\end{array}$ & 4,060 & 4,460 & 3,890 & 0,5700 & 22,08 \\
\hline $\begin{array}{c}\text { AISI 409 1,2 } \\
\text { Welder }\end{array}$ & 5,070 & 3,140 & 2,010 & 1,130 & 34,78 \\
\hline $\begin{array}{c}\text { AISI 409 1,2 } \\
\text { FIP }\end{array}$ & 7,660 & 5,270 & 3,980 & 1,290 & 26,22 \\
\hline
\end{tabular}

The Table 4 shows the pit corrosion rate for stainless steels studied at same test conditions, such as samples dived in $\mathrm{FeCl}_{3}$ solution during 72h. It is possible to note 409 steel presented a higher 
corrosion rate in comparison to 439 steel. As expected, this fact occurred due to more quantities of alloy elements, as chromium and molybdenum, which both collaborate to better pit corrosion resistance.

Comparing the PRE (Pitting Resistance Equivalent), methodologies applied for evaluating level of corrosion resistance taking in consideration the chemical composition is stainless steels, noted that PRE in the 409 steel is lower than 439 steel, as consequent of that, a lower corrosion resistance should be expected.

Other important discussion is related to welding speed in different processes, it was expected that faster welding process should heating less than slower process, and as consequence of that, it should influence positively the corrosion rate, but at this study, even the steel 409 has been welded manually in shorter times, it presented more intense corrosion rate. According to Agarelli (2017), stainless steels exposed in high temperature during long welding times causes increase of grain boundaries at the TAZ regions and a reduction of mechanical strength.

Table 4. Solving the corrosion rate according to ASTM G48 method A

\begin{tabular}{|c|c|c|c|c|c|}
\hline \multicolumn{6}{|c|}{ Corrroion Rate (mm/year) } \\
\hline & $\begin{array}{l}\text { Area } \\
\left(\mathbf{c m}^{2}\right)\end{array}$ & Initial mass (g) & $\begin{array}{l}\text { Final mass } \\
\text { Final (g) }\end{array}$ & Lost mass $(g)$ & $\begin{array}{l}\text { Corrosion rate } \\
\text { (mm/Ano) }\end{array}$ \\
\hline $\begin{array}{c}\text { AISI } 4391,5 \\
\text { welder }\end{array}$ & 6.930 & 6.332 & 6.329 & 0.002000 & 0.1490 \\
\hline $\begin{array}{c}\text { AISI } 4391,5 \\
\text { FIP }\end{array}$ & 11.80 & 5.683 & 5.682 & 0.001000 & 0.03600 \\
\hline $\begin{array}{l}\text { AISI } 4091,2 \\
\text { welder }\end{array}$ & 8.030 & 5.885 & 2.510 & 3.375 & 236.0 \\
\hline $\begin{array}{c}\text { AISI } 4091,2 \\
\text { FIP }\end{array}$ & 9.200 & 4.602 & 1.618 & 2.984 & 182.1 \\
\hline
\end{tabular}

\section{CONCLUSION}

The current study focused on two types of welding processes performed in two stainless steels, and concluded that:

- The presence of alloy element quantity is an important factor for increasing the corrosion resistance;

- Test of intergranular corrosion in 409 steels showed that presence of Titanium contributed positively for attenuating it, reaching good comparative results in reference to 439 steels;

- The 439 stainless steels presented less pit corrosion than 409 steel, certainly due to more quantity of alloy elements.

- Although the manual welding process had heated less the base metal in 409 steel, the comparative corrosion results against 439 steel was worst. Maybe those discrepant results could be influenced by a poor accuracy obtained in mass lost test, different from the more accurate electrochemical tests (Lebrão 1998). 


\section{ACKNOWLEDGMENTS}

The authors would like to thank General Motors Mercosul and IMT - University of Engineering Maua for supporting this study.

\section{CONTACT INFORMATION}

- Susana Marraccini Giampietri Lebrão - susana.lebrao@maua.br

- Marco Colosio - marco.colosio@gm.com

- Jose A. Castillo - jose.lara@fsa.br

\section{REFERENCES}

AGARElli, G. ; LiMA, W. M. ; LEBRÃO, S. M. G. ; LARA, J. A. C. ; COLOSIO, M. A. . Análise da sensitização de juntas soldadas em aços inoxidáveis AISI 409 e AISI 439 para uso em sistema de exaustão veicular. In: 72o Congresso Internacional da ABM, 2017, São Paulo, 2017.

ASTM A763 - Standard Practices for Detecting Susceptibility to Intergranular Attack in Austenitic Stainless Steels. 2015.

ASTM G1 - Standard Practice for Preparing, Cleaning, and Evaluating Corrosion Test Specimens. 2011.

ASTM G48 - Standard Test Methods for Pitting and Crevice Corrosion Resistance of Stainless Steels and Related Alloys by Use of Ferric Chloride Solution. 2015.

Cobb, Harold M. The History of Stainless Steel - ASM Handbook, ASM International, 2010.

Ferreira, Demostenes F., Soldabilidade do Aço Inoxidável Ferrítico. UFU (Universidade Federal de Uberlândia), Symposium of after graduation in mechanical engineering. 2006.

Lebrão, S.M.G. Investigação sobre a resistência à corrosão intergranular do aço inoxidável austenítico UNS S31254. Thesi of doutorado, EPUSP, São Paulo, 1998.

Lima, Luciana I. L.. Metodologia para avaliação da corrosão da zona termicamente afetada de aço inoxidável ferrítico AISI 439 soldado. UFMG (Universidade Federal de Minas Gerais), Program of de after graduation in mechanical engineering, 2007.

Mei, P. R.; Silva, A. L. C. Aços e ligas especiais. 2 ed. Sumaré, SP: Eletrometal S. A. Metais Especiais, 1988.

Modenesi, P. J., Apostila Soldabilidade dos Aços Inoxidáeis, Volum 1, SENAI, 2001

Serna-Giraldo, C. A. Resistencia à Corrosão Intergranular UNS S43000: avaliação por método de reativação eletroquímica, efeito de tratamento isotérmico e mecanismo de sensitização. Thesi of Doutorado. Escola Politécnica da Universidade of São Paulo. 2006

SERNA-GIRALDO, Carlos Augusto et al. Investigação do efeito do teor de intersticiais sobre o grau de sensitização em aços inoxidáveis ferríticos a $600^{\circ} \mathrm{C}$. Rev. Esc. Minas. 2007, vol.60, n.1, pp.49-54. 